\title{
Hypoglycemic Activity of To-Kai-San (Chinese Medicines) in Normal and KK-Ay Mice
}

\author{
Toshihiro Miura, ${ }^{1, *}$ Masako NodA, ${ }^{1}$ Tomoji Fukunaga, ${ }^{2}$ \\ and Kou FURUTA ${ }^{2}$ \\ ${ }^{1}$ Suzuka University of Medical Science and Technology, \\ Suzuka, Mie 510-02, Japan \\ ${ }^{2}$ Mayado Pharmaceutical Co. Ltd., Kobe, Hyogo 651-21, Japan
}

(Received April 19, 1996)

\begin{abstract}
Summary The hypoglycemic effect of To-Kai-San (TS) was studied in normal mice, streptozotocin-induced diabetic mice, one of the animal models of insulin-dependent diabetes mellitus (IDDM) with hypoinsulinemia, and KK-Ay mice, one of the animal models of non-insulindependent diabetes mellitus (NIDDM) with hyperinsulinemia. TS $(1,500$ $\mathrm{mg} / \mathrm{kg}$ ) reduced the blood glucose of the KK-Ay mice from $441 \pm 36$ to $285 \pm 52 \mathrm{mg} / 100 \mathrm{ml} 7 \mathrm{~h}$ after a single oral administration $(p<0.001)$. However, no changes in blood glucose were observed in the normal and STZ-induced diabetic mice. TS also decreased the blood glucose 20 days after repeated administration to normal and KK-Ay mice. In addition, TS-treated KK-Ay mice showed decreased plasma insulin levels after both single and repeated administration. From these findings, it is believed that TS may require the presence of insulin to display its activity.

Key Words hypoglycemic activity, To-Kai-San, normal mice, KK-Ay mice
\end{abstract}

The traditional use of medicinal plants for the treatment of diabetes mellitus greatly declined in developed countries after the introduction of insulin in 1921. In the last few years, serious attempts have been made to develop new easy-to-use, non-parenteral forms of insulin, but the attempts have yielded poor results to date. On the other hand, there is a growing need for new oral antidiabetic drugs such as CS-045 (1) to serve as an alternative therapy in non-insulin-dependent diabetes mellitus (NIDDM). The plant kingdom is a wide field to look for effective oral hypoglycemics. More than 400 species have been reported to display hypoglycemic effects, but only a few of them have been investigated (2-4). Under the present circumstances, many reports about diabetes agents were investigated using streptozotocin, an insulin-dependent diabetes mellitus (IDDM); however, very few reports about NIDDM have been presented.

\footnotetext{
* To whom correspondence should be addressed.
} 
Table 1. Composition of To-Kai-San.

\begin{tabular}{lc}
\hline & To-Kai-San \\
& $(\%)$ \\
\hline Bakumontou (the tuber of Ophiopogon japonicus Ker-Gawler) & 12.0 \\
Ninjin (the radix of Panax ginseng C. A. Meyer) & 8.0 \\
Kakkon (the radix of Pueraria lobata Ohwi) & 12.0 \\
Jiou (the radix of Rhmannia glutinosa Liboschitz ver) & 12.0 \\
Chimo (the rhizoma of Anemarrhena asphodeloides Bunge) & 10.0 \\
Karokon (the radix of Trichosanthes kirilowii Maximowicz) & 12.0 \\
Bukuryou (Poria cocos) & 12.0 \\
Gomishi (the fruit of Schisandra chinensis Baillon) & 6.0 \\
Kanzou (the radix of Glycyrrhiza uralensis Fisher) & 6.0 \\
Tarakon (the radix of Aralia elata Seemann) & 10.0 \\
\hline
\end{tabular}

Many years ago, diabetes was not diagnosed because there was no measurement method for insulin. However, many medicines have been used for conditions like diabetes, polyurea, polydipsia and dehydration. From this point of view, some of them applied to diabetic agents.

To-Kai-San (TS) has been used as a medicine for diabetes. The constituents of TS have been indicated to include 10 raw medicines (Table 1) (5). TS has been clinically taken at the rate of one dose $(2 \mathrm{~g})$ three times a day during each meal. However, there is no experimental evidence of the hypoglycemic effect of this medicine. Furthermore, it is not known whether TS will be effective for IDDM or NIDDM. The purpose of this study was to examine the hypoglycemic effect using two types of diabetic mice.

\section{MATERIALS AND METHODS}

Materials. To-Kai-San (crude powder extract, TS) was obtained from Mayado Co., Hyogo, Japan. The TS properties include: (1) heavy metal by the J.P. test; (2) the water extract is more than 55\%; and (3) the ash content is less than 7.0\%. The Glycyrrhizae radix of TS involved 3-7\% glycyrrhizin. The TS was dissolved in distilled water.

Animals. Adult male ddY mice (SLC, Shizuoka, Japan), 5-weeks-old and weighing $22-25 \mathrm{~g}$, were used. The mice were housed in an air-conditioned room at $22 \pm 2{ }^{\circ} \mathrm{C}$ with a $12 \mathrm{~h} \mathrm{light/dark} \mathrm{cycle} \mathrm{(light:} \mathrm{9:00} \mathrm{am} \mathrm{to} \mathrm{9:00} \mathrm{pm).} \mathrm{The} \mathrm{animals}$ were kept in the experimental animal room for seven days with free access to food (Table 2) and water (tap water). For the determination of blood glucose and insulin levels, blood samples were withdrawn from the cavernous sinus with a capillary under non-anesthesia and nonfasting. All of the experiments were conducted under these conditions.

Streptozotocin-induced diabetic mice were produced by injecting the mice 
Table 2. Composition of the diets (\%).

\begin{tabular}{lr}
\hline Ingredients & \\
\hline Casein & 25.0 \\
DL-Methionine & 0.3 \\
Corn starch & 44.7 \\
Sucrose & 10.0 \\
Corn oil & 7.0 \\
Cellulose & 5.0 \\
Vitamin mix & 1.0 \\
Mineral mix & 7.0 \\
\hline Total & 100.0 \\
\hline
\end{tabular}

intravenously with $150 \mathrm{mg} / \mathrm{kg}$ body weight streptozotocin (STZ, Sigma) (150 mg

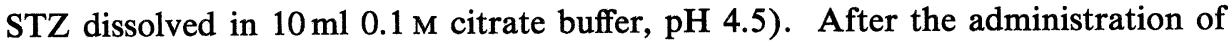
STZ, the animals were kept with free access to food and water. Eight days after the injection of STZ, the blood glucose levels of all the mice were determined.

Male KK-Ay mice, 12-weeks-old and weighing 39-43 g, were used. STZ and KK-Ay mice with blood glucose levels above $300 \mathrm{mg} / 100 \mathrm{ml}$ two days before the experiment were considered to be diabetic and were used in this study. Five to six animals were used for each group. The studies were started at 10:00-11:00 am, and the blood samples after repeated administration of TS were taken at 10:0011:00 am. The oral administrations of TS were given on a compulsory basis. TS concentrations $(150,500$ and $1,500 \mathrm{mg}$ ) were dissolved in $20 \mathrm{ml}$ distilled water. All the experimental conditions for TS were non-fasting, and free access to food and water.

Determination of blood glucose, cholesterol and triglyceride. Blood glucose, cholesterol, triglyceride and insulin levels were determined using commercial reagents ("Glucose C-Test Wako," "Cholesterol E-Test Wako," "Triglyceride G-Test Wako" and "Insulin-EIA Test," Wako Pure Chemical Industries, Ltd.). All the data were expressed as $\mathbf{M} \pm$ SEM and Student's $t$-test was used for the statistical analysis. The values were considered to be significantly different when the $p$ value was less than 0.05 .

\section{RESULTS}

Effect of a single administration of TS on normal mice, streptozotocin-induced diabetic mice (IDDM) and KK-Ay mice (NIDDM)

The mean blood glucose levels of the KK-Ay mice at various time intervals after the oral administration of TS are shown in Fig. 1. TS at $1,500 \mathrm{mg} / \mathrm{kg}$ lowered the blood glucose level from $441 \pm 36$ to $285 \pm 52 \mathrm{mg} / 100 \mathrm{ml}(p<0.05) 7 \mathrm{~h}$ after administration. TS at $500 \mathrm{mg} / \mathrm{kg}$ decreased the blood glucose level from $500 \pm 48$ to $263 \pm 39 \mathrm{mg} / 100 \mathrm{ml}(p<0.05) 7 \mathrm{~h}$ after administration. The plasma insulin levels in 


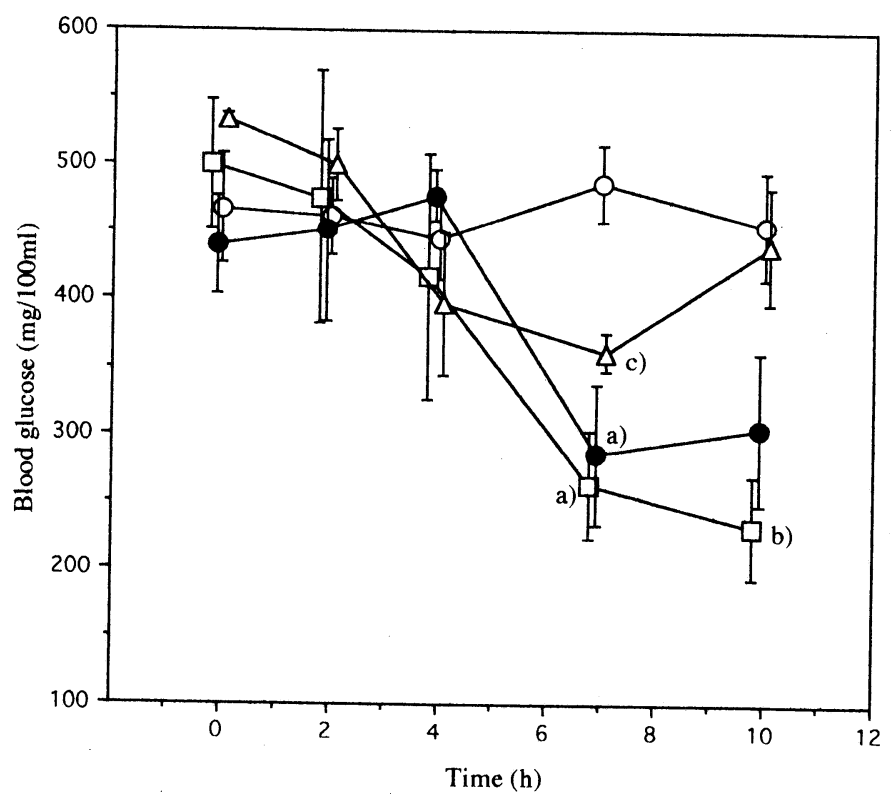

Fig. 1. Effect of TS on blood glucose in KK-Ay mice. Each point indicates the $\mathbf{M}$ $\pm \mathrm{SE}$ of 4-6 mice. Significantly different from prevalue, a) $p<0.05$, b) $p<0.01$. , control; $\triangle$, TS $150 \mathrm{mg} / \mathrm{kg}$; $\square$, TS $500 \mathrm{mg} / \mathrm{kg}$;, TS $1,500 \mathrm{mg} / \mathrm{kg}$.

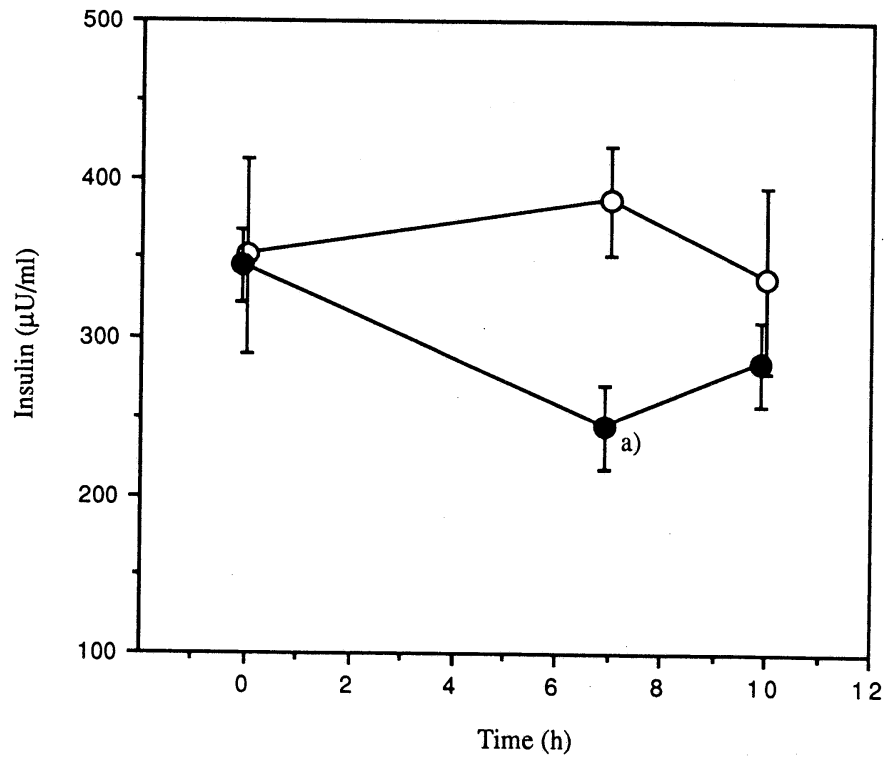

Fig. 2. Effect of TS on insulin concerntration in KK-Ay mice. Each value represents the $\mathbf{M} \pm \mathbf{S E}$ of five mice. Significantly different from TS $0 \mathrm{mg} / \mathrm{kg}$, a) $p<$ 0.05. O, TS $0 \mathrm{mg} / \mathrm{kg}$;, TS $1,500 \mathrm{mg} / \mathrm{kg}$. 
the TS-treated $(1,500 \mathrm{mg} / \mathrm{kg})$ mice decreased at $7 \mathrm{~h}$ (Fig. 2), indicating that TS improved hyperinsulinemia in KK-Ay mice.

On the other hand, there was no significant difference in the levels between the control and TS-treated groups in normal mice (control $(\mathrm{mg} / 100 \mathrm{ml}): 190 \pm 11$ at $0 \mathrm{~h}, 202 \pm 1$ at $2 \mathrm{~h}, 188 \pm 12$ at $4 \mathrm{~h}, 184 \pm 8$ at $7 \mathrm{~h}, 176 \pm 11$ at $10 \mathrm{~h}$; TS: $193 \pm 8$ at $0 \mathrm{~h}$, $180 \pm 5$ at $2 \mathrm{~h}, 174 \pm 7$ at $4 \mathrm{~h}, 167 \pm 6$ at $7 \mathrm{~h}, 166 \pm 9$ at $10 \mathrm{~h}$ ). In addition, no changes in blood glucose were observed in the TS-treated $(1,500 \mathrm{mg} / \mathrm{kg})$ STZ-induced diabetic mice (control $(\mathrm{mg} / 100 \mathrm{ml}): 589 \pm 22$ at $0 \mathrm{~h}, 531 \pm 44$ at $2 \mathrm{~h}, 495 \pm 27$ at $4 \mathrm{~h}$, $527 \pm 53$ at $7 \mathrm{~h}, 512 \pm 40$ at $10 \mathrm{~h}$; TS $(\mathrm{mg} / 100 \mathrm{ml}): 632 \pm 15$ at $0 \mathrm{~h}, 533 \pm 14$ at $2 \mathrm{~h}$, $543 \pm 13$ at $4 \mathrm{~h}, 538 \pm 27$ at $7 \mathrm{~h}, 597 \pm 49$ at $10 \mathrm{~h}$ ).

\section{Effect of repeated administration of TS on normal, STZ and KK-Ay mice}

The effect of the repeated administration of TS on the blood glucose level in normal mice is shown in Fig. 3 . TS-treated $(1,500 \mathrm{mg} / \mathrm{kg})$ mice showed a significant decrease in blood glucose level after 20 days when compared with control mice. However, there were no significant differences in the levels of total cholesterol and triglyceride between the control and TS-treated groups (Total cholesterol: 156 \pm 10 and $156 \pm 7 \mathrm{mg} / 100 \mathrm{ml}$ for control and TS, respectively; triglyceride: $151 \pm 7$ and $162 \pm 12 \mathrm{mg} / 100 \mathrm{ml}$ for control and TS, respectively). The mean blood glucose levels in KK-Ay mice after 20 days are shown in Fig. 4. TS-treated $(1,500 \mathrm{mg} / \mathrm{kg})$ KK-Ay mice had a decreased blood glucose level after 20 days (538 \pm 8 and $348 \pm$ $43 \mathrm{mg} / 100 \mathrm{ml}$ for control and TS, respectively, $p<0.01$ ) (Fig. 4) as well as decreased insulin level $(391 \pm 11$ and $319 \pm 21 \mu \mathrm{U} / \mathrm{ml}$ for control and TS, respectively,

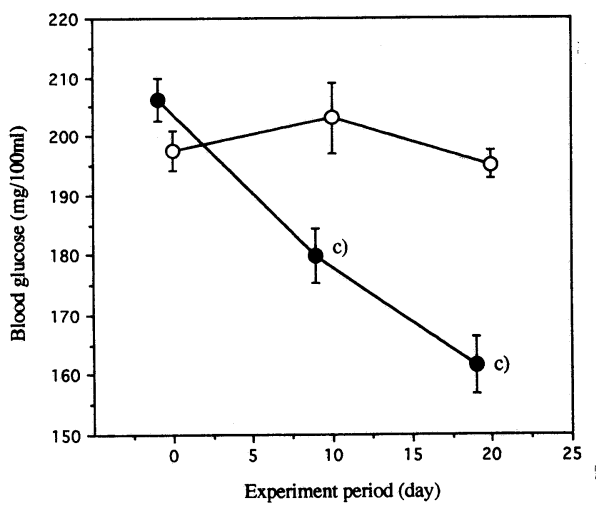

Fig. 3

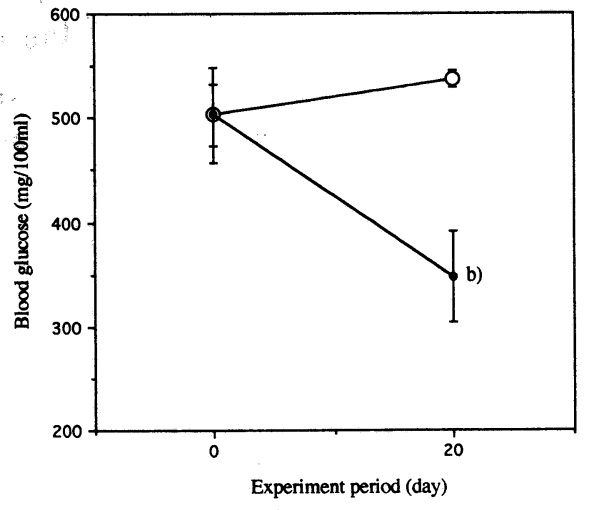

Fig. 4

Fig. 3. Effect of repeated administration of TS on blood glucose in normal mice. Each point indicates the $M \pm S E$ of $10-12$ mice. Significantly different from the prevalue, c) $p<0.001$. $\bigcirc$, TS $0 \mathrm{mg} / \mathrm{kg}$; $\bullet$, TS $1,500 \mathrm{mg} / \mathrm{kg}$.

Fig. 4. Effect of repeated administration of TS on blood glucose in KK-Ay mice. Each point indicates the $\mathbf{M} \pm \mathbf{S E}$ of five mice. Significantly different from TS $0 \mathrm{mg} / \mathrm{kg}$, b) $p<0.01$. O, TS $0 \mathrm{mg} / \mathrm{kg} ; \bullet$, TS $1,500 \mathrm{mg} / \mathrm{kg}$. 




Fig. 5. Effect of repeated administration of TS on insulin concentration in KK-Ay mice. Each value represents the $\mathrm{M} \pm \mathrm{SE}$ of five mice. Significantly different from TS $0 \mathrm{mg} / \mathrm{kg}, \mathrm{b}$ ) $p<0.01$.

$p<0.01$ ) (Fig. 5). However, TS-treated $(1,500 \mathrm{mg} / \mathrm{kg}$ ) STZ mice did not show a decrease in blood glucose $(804 \pm 9$ and $857 \pm 8 \mathrm{mg} / 100 \mathrm{ml}$ for control and TS, respectively).

\section{DISCUSSION}

This study clearly shows that TS produced consistent hypoglycemic effects in normal and KK-Ay mice, one of the animal models of non-insulin-dependent diabetes mellitus (NIDDM) with hyperinsulinemia. KK-Ay mice, which are known for genetically induced diabetes, including ob/ob mice (6) and KK mice (7), were hyperinsulinemia as a result of insulin resistance (8). However, TS (1,500 $\mathrm{mg} / \mathrm{kg}$ ) had no effect on the blood glucose levels of STZ-induced diabetic mice, one of the animal models of insulin-dependent diabetes mellitus (IDDM) with hypoinsulinemia (9). TS-treated KK-Ay mice showed decreased blood glucose level and improved hyperinsulinemia, indicating that TS may relax the insulin resistance. The effect of TS concentrations of 500 and $1,500 \mathrm{mg} / \mathrm{kg}$ was not different in KK-Ay mice. From this finding, a TS concentration of $500 \mathrm{mg} / \mathrm{kg}$ is the maximum dose for the hypoglycemic effect. In addition, the repeated administration of TS decreased the blood glucose levels in normal and KK-Ay mice for 20 days. However, the repeated administration of TS did not decrease the blood glucose levels in streptozotocin-induced diabetic mice. From these findings, it is believed that TS may require the presence of insulin to display its activity. It is possible to elevate insulin sensitivity in peripheral tissues, because TS decreases the blood glucose level in normal mice. In terms of a hypoglycemic effect, the blood glucose level after a single administration was lower than that in KK-Ay mice after repeated administrations, suggesting that TS enhanced the metabolic enzyme. The dose of 1,500 $\mathrm{mg} / \mathrm{kg}$ is ten times that for humans. Many traditional medicines decrease the blood glucose level in such a high dose as this; for example, Centaurea corcubionensis 
$(2.5-10 \mathrm{~g} / \mathrm{kg})(10)$ and Momordica charantia $(4 \mathrm{~g} / \mathrm{kg})(11)$.

In regards to toxicity, the toxicity of TS seems to be very low $\left(\mathrm{LD}_{50} \gg 1,500\right.$ $\mathrm{mg} / \mathrm{kg}$ ) (data not shown). Moreover, TS-treated $(1,500 \mathrm{mg} / \mathrm{kg}$ ) mice did not show any obvious stimulus action, suggesting that TS is a medicine with lower toxicity. diabetes.

In conclusion, the hypoglycemic effect of TS differs according to the type of

\section{REFERENCES}

1) Masuda, K., Okamoto, Y., Tsuura, Y., Kato, S., Miura, T., Tsuda, K., Horikoshi, H., Ishida, H., and Seino, Y. (1995): Effects of Troglitazone (CS-045) on insulin secretion in isolated rat pancreatic islets and HIT cells: an insulinotropic mechanism distinct from glibenclamide. Diabetologia, 38, 24-30.

2) Miura, T., and Kato, A. (1995): The difference in hypoglycemic action between Polygonati Rhizoma and Polygonati Officinalis Rhizoma. Biol. Pharm. Bull., 18, 1605-1606.

3) Miura, T., Kato, A., Usami, M., Kadowaki, S., and Seino, Y. (1995): Effect of Polygonati Rhizoma on blood glucose and facilitative glucose transporter isoform 2 (GLUT2) mRNA expression in Wistar fatty rats. Biol. Pharm. Bull., 18, 624-625.

4) Miura, T., Nishiyama, Y., Ichimaru, M., Moriyasu, M., and Kato, A. (1996): Hypoglycemic activity and structure-activity relationship of iridoidal glycosides. Biol. Pharm. Bull., 19, 160-161.

5) Miyake, H. (1994): The over the counter in 1994-1995. The Information Center of Japanese Drug, Yakujijihou Publishing, Tokyo, 1132.

6) Coleman, D. L. (1982): Diabetes-obesity syndromes in mice. Diabetes, 31 (Suppl. 1), 1-6.

7) Nakamura, M. (1962): A diabetic strain of the mouse. Proc. Jpn. Acad., 38, 348-352.

8) Nishimura, M. (1969): Breeding of mice strains for diabetes mellitus. Exp. Animal, 18, $147-157$.

9) Rakieten, N., Rakieten, M. L., and Nadkarni, M. V. (1963): Studies on the diabetogenic action of streptozotocin. Cancer Chemother. Rep., 29, 91-98.

10) Chucla, M. T., Lamela, M., Gato, A., and Cadavid, I. (1988): Centaurea corcubionensis: A study of its hypoglycemic activity in rats. Planta Med., 52, 107-109.

11) Caroline, D., Cartwright, T., Provost, J., and Bailey, C. J. (1990): Hypoglycemic effect of Momoridica charantia extracts. Planta Med., 56, 426-429. 